Lipina M., Mukhanov V., Karpashevich A., Goncharov E., Maglevaniy S., Lubiatowski P. Russian cultural adaptation of main shoulder assessment scores: ASES, UCLA, Constant score, SST (Part 1). Preliminary study. Issue Rehabil. Orthop. Neurophysiol. Sport Promot. 2018; 25: 45-57. DOI: 10.19271/IRONS-000081-2018-25.

\section{RUSSIAN CULTURAL ADAPTATION OF MAIN SHOULDER ASSESSMENT SCORES: ASES, UCLA, CONSTANT SCORE, SST (PART 1). PRELIMINARY STUDY}

Marina Lipina ${ }^{1}$

Victor Mukhanov ${ }^{1}$

Alexander Karpashevich ${ }^{1}$

Evgeniy Goncharov ${ }^{4}$

Sergey Maglevaniy ${ }^{5}$

Przemysław Lubiatowski ${ }^{2,3}$

${ }^{1}$ Federal Research and Clinical Center of Federal Medical Biological Agency, Russia

${ }^{2}$ Department Orthopaedics, Traumatology and Hand Surgery, Poznan University of Medical Sciences, Poland

${ }^{3}$ Rehasport Clinic, Poznan, Poland

${ }^{4}$ Central Clinical Hospital, Russian Academy of Science, Russia

5People's Friendship University of Russia, Russia

\section{SUMMARY}

Introduction

For reliable using of the selected surveys in other than originally assigned to the questionnaire, linguistic and cultural circles, it is necessary to perform cultural adaptation, which consists of forward-backward-translation according to the strict guidelines.

\section{Aim}

The aim of study was to translate, culturally adapt a Russian version of four main questionnaires to provide a subjective method for the evaluation of shoulder impairment for Russian patients.

Material and methods

Russian version of the questionnaires was adapted from original (English) version
ROSYJSKA ADAPTACJA KULTUROWA FORMULARZY OGÓLNEJ OCENY BARKU Z ZASTOSOWANIEM DO BOLESNEGO BARKU: ASES, UCLA, CONSTANT SCORE, SST (CZĘŚĆ I) BADANIE WSTĘPNE.

Marina Lipina ${ }^{1}$

Victor Mukhanov ${ }^{1}$

Alexander Karpashevich ${ }^{1}$

Evgeniy Goncharov ${ }^{4}$

Sergey Maglevaniy ${ }^{5}$

Przemysław Lubiatowski ${ }^{2,3}$

${ }^{1}$ Federal Research and Clinical Center of Federal Medical Biological Agency, Russia ${ }^{2}$ Katedra i Klinika Traumatologii, Ortopedii i Chirurgii Ręki, Uniwersytet Medyczny w Poznaniu, Polska

${ }^{3}$ Rehasport Clinic, Poznań, Polska

${ }^{4}$ Central Clinical Hospital, Russian Academy of Science, Russia

5People's Friendship University of Russia, Russia

\section{STRESZCZENIE}

Wstęp

W celu rzetelnego wykorzystania wybranych ankiet w innych niż pierwotnie przypisanych do kwestionariusza kręgów językowych i kulturowych, konieczne jest przeprowadzenie adaptacji kulturowej, na którą składa się tłumaczenie „dwujęzyczne’ zgodnie ze ścisłymi wytycznymi.

\section{Cel}

Celem badań było przetłumaczenie, adaptacja kulturowa rosyjskiej wersji czterech głównych kwestionariuszy, aby zapewnić obiektywną metodę ogólnej oceny zaburzeń funkcji barku u pacjentów rosyjskich.

\section{Materiał i metody}

Rosyjska wersja kwestionariuszy została zaadaptowana z oryginalnej (angielskiej) 
according to the widely used guidelines of Beaton.

\section{Results}

Each of the resulting versions has been adjusted to Russian specifics

\section{Conclusions}

All the questionnaires translated and analyzed are widely used in many countries to assess the condition of the shoulder joint in patients with painful shoulder. Even so, given the specifics that every individual country possesses, each questionnaire should be adjusted in accordance with the specifics of the country where it is set to be used. What is most useful and efficient is multistage translation, where the resulting versions are analyzed, corrected and synthesized to obtain a version that is best adjusted to the local conditions and the specifics of the target language, as opposed to straightforward language-to-language translation.

Keywords: cultural adaptation, questionnaire, painful shoulder, language-to-language English and Russian translation

Date received: 14th January 2018

Date accepted: 18th March 2018

\section{Introduction}

Shoulder pain is common in patients with degenerative or inflammatory disorders with $7 \%$ prevalence in the population and is one of the most frequent musculoskeletal symptoms after low back and neck pain(Luime et al. , 2004; Feleus et al., 2008; Grevinget al., 2012).

The amount of operative management of shoulder disorders, including arthroscopic shoulder procedures for rotator cuff, instability, adhesive capsulitis, synovitis, biceps tendon disease, subacromion impingement and glenohumeral joint replacement, patient-reported shoulder specific clinical measures increases (Ebrahimzadeh et al., 2015). Furthermore, there are other non-traumatic wersji zgodnie z powszechnie stosowanymi wytycznymi firmy Beaton.

\section{Wyniki}

Każda z powstałych wersji została dostosowana do rosyjskiej specyfiki oceny.

\section{Wnioski}

Wszystkie kwestionariusze przetłumaczone i przeanalizowane są szeroko stosowane w wielu krajach w celu oceny funkcjonalnej stawu barkowego u pacjentów $\mathrm{z}$ bolesnym ramieniem. Mimo to, biorąc pod uwagę specyfikę każdego kraju, każdy kwestionariusz powinien zostać dostosowany zgodnie ze specyfiką kraju, w którym ma być wykorzystany. Najbardziej przydatne i wydajne jest tłumaczenie wielostopniowe, w którym powstałe wersje są analizowane, korygowane i syntetyzowane w celu uzyskania wersji najlepiej dostosowanej do warunków lokalnych i specyfiki języka docelowego, w przeciwieństwie do prostego tłumaczenia językowego.

Słowa kluczowe: adaptacja kulturowa, kwestionariusz, bolesne ramię, tłumaczenie oceny funkcjonalnej angielskie i rosyjskie

Data otrzymania: 14 stycznia 2018

Data zaakceptowania: 18 marca 2018

pathologies that indirectly affect the function of the upper limbs such as neuropathy, radiculopathy, cervical spine disease and tumors. Shoulder evaluation scores are very useful in the process of diagnosing and managing patients who present to their family physician, orthopedic surgeon or physiotherapist with shoulder related problems (Ślęzak et al., 2016). This indicates the importance of patients' self-evaluation regarding their health status and quality of life related to their presenting disease in order to assess treatment efficacy. It is important to choose questionnaires that are valid, reliable and sensitive to clinical changes. There are no valid patient-based assessment tools for

46 Issues of Rehabilitation, Orthopaedics, Neurophysiology and Sport Promotion - IRONS 
the shoulder joint in Russian language. The only questionnaires that cover partially extent of the shoulder joint, and which have an official translation are DASH and QuickDASH (Disabilities of the Arm, Shoulder and Hand) (http://www.dash.iwh.on.ca/available-translations) (Yaghjyan et al., 2005).

More than 40 instruments have been developed for measuring treatment outcomes in shoulder disorders (Harvie et al., 2005; Roe et al., 2013; Wylie et al., 2014). Most of have been developed in English-speaking countries. The self-assessment questionnaires must be readily understood by patients (Ślęzak et al.,2016).The use of questionnaires that are not satisfying the original may give rise to unreliable to tangle results, which could limit the exchange of information among the scientific community. For reliable using of the selected surveys in other than originally assigned to the questionnaire, linguistic and cultural circles, it is necessary to perform cultural adaptation, which consists of forward-backward-translation according to the strict guidelines (Beaton et al.,1996; Beaton et al., 1998; Ślęzak et al.,2016) and validation in clinical conditions of the translated questionnaire (Michener et al., 2002; Neto et al. 2013; Gaudelli et al. 2014), unfortunately only in a few countries cultural adaptation and validation of the shoulder scores have been made (Table 1) (Ślęzak et al.,2016).

\section{Aim}

The aim of study was to translate, culturally adapt a Russian version of four main questionnaires to provide a subjective method for the evaluation of shoulder impairment for Russian patients.

\section{Materials and methods}

Translation and cultural adaptation

Russian version of the questionnaires was adapted from original (English) version according to the widely used guidelines of Beaton (Beaton et al.,1996; Beaton et al., 1998). The questionnaires were initially translated from English into the Russian language by two independent translators whose mother language was Russian. During this process, the translators had the task to transform all the measures into metric system (i. e. pounds to kilograms, yards to meters, gallons and pints to liters).The two translators have different profiles (first- medical and the second a layman in relation to the subject). Then the two translations produced one common translation, with a written report carefully documenting the synthesis process, each of the issues addressed, and how they were resolved. The next stage was completed with this version of the questionnaire. A translator then translated the questionnaire back into the original language totally blind to the original version. This is a process of validity checking to make sure that the translated version is reflecting the same item content as the original versions. The back-translations were produced by two persons with the source language (English) as their mother one. Again, the two translators comprised of a layman and a medical professional. In the fourth stage, a committee (consisting of all the translators, a project manager, a principal investigator, statistician and linguist) compared the two versions, the original and reverse-translated. The documents were analyzed if the translation was not different from the original version, and disagreements discussed to get the final version. A semi-final Russian language version was then created. The last step was testing the questionnaire on a group of 35 people. This investigation was approved by research ethical board. The patients were informed about the study and signed an informed consent. Each patient completed the questionnaire, and was interviewed to probe about what he or she thought was meant by each questionnaire item and the chosen response (Figure 1). 
Table 1. The available cultural adaptations of evaluation of forms for painful shoulder.

\begin{tabular}{|c|c|c|}
\hline Questionnaire & Cultural adaptation & \\
\hline SSI - ASES & $\begin{array}{l}\text { Turkish } \\
\text { Italian } \\
\text { Portuguese } \\
\text { Portuguese for Brazilian } \\
\text { German } \\
\text { Arabic } \\
\text { Finnish } \\
\text { Polish }\end{array}$ & $\begin{array}{l}\text { Celik et al. } 2013 \\
\text { Padua et al. } 2010 \\
\text { Angst et al. } 2011 \\
\text { Knaut et al. 2010; Puga et al. } 2012 \\
\text { Goldhahn et al. } 2008 \\
\text { Yahia et al. } 2011 \\
\text { Pitulainen et al. } 2014 \\
\text { Ślęzak et al. } 2016\end{array}$ \\
\hline UCLA & $\begin{array}{l}\text { Portuguese for Brazilian } \\
\text { Italian } \\
\text { Polish }\end{array}$ & $\begin{array}{l}\text { Puga et al. } 2012 \\
\text { Marchese et al. } 2012 \\
\text { Ślęzak et al. } 2016\end{array}$ \\
\hline SST & $\begin{array}{l}\text { Lithuania } \\
\text { Portuguese for Brazilian } \\
\text { Dutch } \\
\text { Italian } \\
\text { Spanish } \\
\text { Persians } \\
\text { Polish }\end{array}$ & $\begin{array}{l}\text { Ryliskis et al. } 2008 \\
\text { Neto et al. } 2013 \\
\text { Lippit et al. } 1993 \\
\text { Marchese et al. } 2012 \\
\text { Membrilla-Mesa et al. } 2015 \\
\text { Naghdi et al. } 2015 \\
\text { Ślęzak et al. } 2016\end{array}$ \\
\hline CS & $\begin{array}{l}\text { Danish } \\
\text { French } \\
\text { Greek } \\
\text { Polish }\end{array}$ & $\begin{array}{l}\text { Ban et al. } 2013 \\
\text { Angst et al. } 2011 \\
\text { Ntourantonis et al. } 2017 \\
\text { Ślęzak et al.2016 }\end{array}$ \\
\hline
\end{tabular}

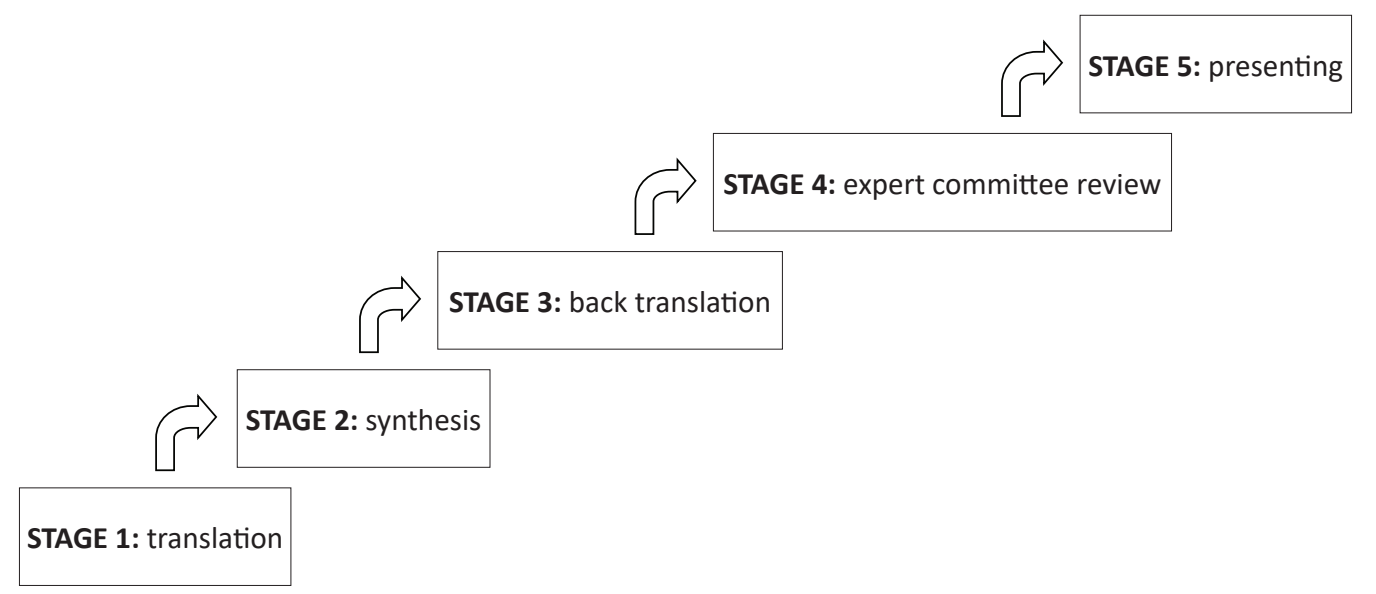

Figure. 1. The steps of translation of a questionnaire.

\section{Questionnaires}

The University of California - Los Angeles (UCLA) Shoulder Scale

This scale was first described in 1981. It was one of the first patient-reported outcome measures for the shoulder and, similarly to the Constant-Murley score, it was not validated in first introduction. It was designed for use in shoulder arthroplasty and later used for other shoulder conditions (Amstutz et al., 1981).This scale has been widely used since its inception in 1986.
Its assessment includes points for pain from 1-10 and points for function from 1-10. Additionally, front active flexion of the shoulder is rated $0-5$ points, the strength of active flexion is $0-5$ points, and patient satisfaction is 0 or 5 points. The strength and range of motion is determined by the examining doctor or physiotherapist while the other parameters are rated by the patient. The highest score healthy patient can achieve is 35 points, any result above 27 points is 
recognized as a good/excellent (satisfactory), and a score of below 27 is deemed fair/ poor (unsatisfactory) (Ellman et al., 1986; Ślęzak et al.,2016).

\section{The Simple Shoulder Test}

The Simple Shoulder Test (STT) was developed by the University of Washington, Department of Orthopedics, Shoulder Team first published in 1992 as a quick, practical and inexpensive patient based and joint specific measurement instrument (Lippitt et al., 1992). It is a self-administered questionnaire designed to document the functional status of a symptomatic shoulder. It consists of 12 'yes' or 'no' questions derived from common shoulder com-plaints. Each question focuses on shoulder function and a specific activity intolerance. STT was developed and test retest reliability, construct validity, responsiveness of the SST have been studied in several studies (Matsen et al., 1995; Beaton et al., 1996; Beaton et al., 1998; Roddey et al., 2000; Romeo et al., 2004; Godfrey et al., 2007; MacDermid et al., 2006), and the SST proved to be simple and effective tool for measuring the results of treatment.

Shoulder Score Index- American Shoulder and Elbow Surgeons (ASES) Shoulder Outcome Score

The research committee of the SSI-ASES developed this score in 1994 to be applicable to all shoulder diagnoses (Richards et al., 1994; Smith et al., 2012). It consists of a physician-rated and a patient-rated questionnaire. The physician-rated outcomes are not commonly reported. The patient-rated questionnaire is divided into three domains that assess (1) pain, (2) instability, and (3) activities of daily living. For the patient-rated assessment, there are ten questions rated on a 4-point ordinal scale (from 0 to 3 ) to give a maximum score of 30 points. This score is then converted to a 100-point scale with higher scores indicating better outcome. The survey score, called the Shoulder Score
Index (SSI) is calculated according to the formula SSI $=(10-[$ score on the pain scale $])$ $\times 5+(5 / 3 \times$ [sum of points for daily living activities]).

This score was validated in a group of patients with a wide range of shoulder diagnoses, treated both operatively and nonoperatively, who ranged from twenty to eighty-one years of age. An estimation of the minimal clinically important difference and the minimal detectable change was 6.4 ASES points and 9.7 ASES points, respectively (Michener et al., 2002; Smith et al., 2012). Another recent estimate of the minimal clinically important difference for nonoperative treatment of rotator cuff disease was between 12 and 17 ASES points.

\section{The Constant score}

The Constant score was devised by C. Constant with the assistance of the Alan Murley during the years 1981-1986. The score was first presented in a university thesis in 1986 and the methodology was published in 1987.This functional assessment score was conceived as a system of assessing the overall value, or functional state, of a normal, a diseased or a treated shoulder. It is composed of objective and subjective sections divided into four subscales, including pain ( 15 points maximum), activities of daily living (20 points maximum), range of motion [ROM] (40 points maximum) and strength ( 25 points maximum). The higher the score the higher the quality of function (minimum 0, maximum 100).

The Societe Europeenne pour la Chiurgie de l'Epauleet du Coude /European Society of shoulder and elbow surgery (SECEC/ESSSE) promotes the Constant-Murley score for a comprehensive and comparable assessment of shoulder function. The score is widely used and accepted throughout the European community as a shoulder golden standard for the assessment of shoulder function (Rocourt et al., 2008). 


\section{Results}

Each of the resulting versions has been adjusted to Russian specifics. Translating The University of California - Los Angeles (UCLA) Shoulder Scale did not present any substantial difficulty. All of the questions therein are well perceived and reproduced.

Translating The Constant score posed certain challenges for a translator not specializing in medicine. Specialist medical terms proved difficult to translate accurately (e.g. anatomic landmarks and shoulder joint movements).

The Shoulder Score Index - American Shoulder and Elbow Surgeons (ASES) Shoulder Outcome Score proved rather easy to understand, with the exception of the necessity to convert measurement units into the ones used in Russia (for example, 10lbs. (4.5 kg)), which was also the case with The Simple Shoulder Test (pounds to kilograms, yards to meters). Additionally, there were troubles associated with the interpretation of 'soft ball' as the game referred to here is not popular in Russia. It was therefore suggested that the questionnaire should refer to a 'tennis ball' instead, as the dimensions of the two kinds of balls are relatively comparable.

All Russian-language versions of the questionnaires are provided below.

Оценочный опросник состояния плеч американских хирургов плечевого локтевого суставов SHOULDER ASSESSMENT FOR AMERICAN SHOULDER AND ELBOW SURGEONS

\begin{tabular}{|c|c|c|}
\hline \multicolumn{3}{|l|}{$\begin{array}{l}\text { Обведите цифру, которая соответствует степени вашей способности выполнять следующие } \\
\text { действия: } \\
\mathbf{0}=\text { не в состоянии; } \mathbf{1} \text { = с большим трудом; } \mathbf{2} \text { = с определенным усилием; } \mathbf{3} \text { = нормально }\end{array}$} \\
\hline ДЕЙСТВИЕ & ЛЕВАЯ РУКА & ПРАВАЯ РУКА \\
\hline 1. Надевание пальто & & \\
\hline 2. Сон на боку, соответствующем стороне болезненной или поврежденной конечности & & \\
\hline 3. Мытье спины/застегивание бюстгальтера за спиной & & \\
\hline 4. Пользование туалетом & & \\
\hline 5. Расчесывание/мытье волос & & \\
\hline 6. Доставание высоко расположенной полки & & \\
\hline 7. Поднимание выше уровня плеча предмета с массой 5 кг & & \\
\hline 8. Метание мяча из-за головы & & \\
\hline 9. Выполнение обычных обязанностей на работе - перечислить: & & \\
\hline 10. Занятия привычными видами спорта - перечислить: & & \\
\hline $\begin{array}{l}\text { Боль } \\
\text { Оцените свое состояние по приведенной ниже шкале - обведите одно из значений от } 0 \text { до } 10 . \\
\text { Насколько интенсивна сегодня испытываемая вами боль? } \\
0=\text { боль отсутствует .......................... } 10 \text { = боль максимальная }\end{array}$ & & \\
\hline 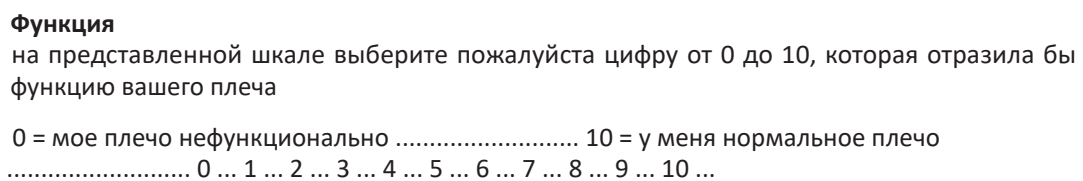 & & \\
\hline
\end{tabular}


Простой тест на состояние плеча

\begin{tabular}{|c|c|c|c|}
\hline Доминирующая рука .................... & $\begin{array}{l}\text { Правая } \\
\text { Левая } \\
\text { Обе (амбидекстаральный) }\end{array}$ & & \\
\hline Исследуемое плечо ..................... & $\begin{array}{l}\text { Правое } \\
\text { Левое }\end{array}$ & & \\
\hline 1. & $\begin{array}{l}\text { Комфортно ли Вашему плечу, когда рука находится в } \\
\text { состоянии покоя и вытянута вдоль туловища? ...................... }\end{array}$ & да & нет \\
\hline 2. & Позволяет ли ваше плечо вам комфортно спать? ................... & да & нет \\
\hline 3. & Можете ли вы достать рукой до спины и заправить кофту? & да & нет \\
\hline $\begin{array}{l}\text { Идентификационный номер/ } \\
\text { паспортные данные пациента } \\
\text {................. }\end{array}$ & 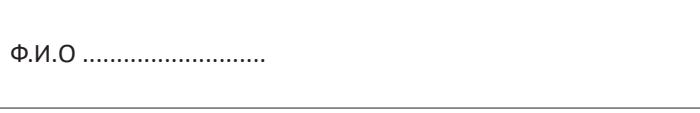 & \multicolumn{2}{|c|}{ Дата............................ } \\
\hline Сторона....Прав....Лев & Тип ЭП.... рев....тот....геми & \multicolumn{2}{|c|}{ Bcero: } \\
\hline Сторона....Прав....Лев & Тип ЭП.... рев....тот....геми & \multicolumn{2}{|c|}{ Bcero: } \\
\hline 4. & $\begin{array}{l}\text { В состоянии ли вы завести ладонь за голову так, чтобы } \\
\text { локоть был обращен строго в сторону? ................... }\end{array}$ & да & нет \\
\hline 5. & $\begin{array}{l}\text { Можете ли вы положить монету на полку } \\
\text { на уровне вашего плеча, не сгибая локоть? }\end{array}$ & да & нет \\
\hline 6. & $\begin{array}{l}\text { Можете ли вы поднять 0,5 кг на уровень плеча, } \\
\text { не сгибая локоть? }\end{array}$ & да & нет \\
\hline 7. & $\begin{array}{l}\text { Можете ли вы поднять 4,5 кг на уровень вашего плеча, не } \\
\text { сгибая локоть? .................. }\end{array}$ & да & нет \\
\hline 8. & $\begin{array}{l}\text { Можете ли вы нести в руке, вытянутой вдоль туловища с } \\
\text { пораженным плечевым суставом, } \\
\text { груз } 10 \text { кг }\end{array}$ & да & нет \\
\hline 9. & $\begin{array}{l}\text { Думаете ли вы, что можете бросить теннисный мяч } \\
\text { пораженной рукой движением снизу вверх } \\
\text { на } 10 \text { метров? }\end{array}$ & да & нет \\
\hline 10. & $\begin{array}{l}\text { Думаете ли вы, что можете бросить мягкий мяч } \\
\text { пораженной рукой ................. движением сверху вниз } \\
\text { на } 20 \text { метров? }\end{array}$ & да & нет \\
\hline 11. & $\begin{array}{l}\text { Можете ли вы помыть спину со стороны } \\
\text { противоположного плеча .................. пораженной рукой? }\end{array}$ & да & нет \\
\hline 12. & Позволяет ли ваше плечо работать полный рабочий день? & да & нет \\
\hline
\end{tabular}

Шкала оценки плечевого сустава Университета Калифорнии, Лос - Анджелес

(The University of California - Los Angeles (UCLA) Shoulder Scale)

ФИО врача

ФИО пациента

На протяжении последних 4 недель

\begin{tabular}{|c|c|c|c|}
\hline \multirow{6}{*}{1.} & \multirow{6}{*}{ Боль } & 1 & $\begin{array}{l}\text { постоянная невыносимая; частое обезболивание сильными } \\
\text { анальгетиками }\end{array}$ \\
\hline & & 2 & $\begin{array}{l}\text { постоянная, но терпимая; } \\
\text { прием анальгетиков при необходимости }\end{array}$ \\
\hline & & 4 & $\begin{array}{l}\text { в состоянии покоя боль минимальная или отсутствует; } \\
\text { присутствует при легкой степени активности; } \\
\text { эпизодически прием салицилатов }\end{array}$ \\
\hline & & 6 & $\begin{array}{l}\text { при тяжелом или определенном виде активности; } \\
\text { частый прием салицилатов }\end{array}$ \\
\hline & & 8 & периодическая или слабая \\
\hline & & 10 & боли нет \\
\hline
\end{tabular}


RUSSIAN CULTURAL ADAPTATION OF MAIN SHOULDER ASSESSMENT SCORES: ASES, UCLA...

\begin{tabular}{|c|c|c|c|}
\hline \multirow{6}{*}{2.} & \multirow{6}{*}{ Функция } & 1 & рука не используется \\
\hline & & 2 & возможны только минимальные движения \\
\hline & & 4 & $\begin{array}{l}\text { возможна мелкая работа по дому или большинство } \\
\text { манипуляций в повседневной жизни }\end{array}$ \\
\hline & & 6 & $\begin{array}{l}\text { большая часть домашней работы, покупки, } \\
\text { вождение - возможны; способны расчесываться, одеваться/ } \\
\text { раздеваться, включая застегивание бюстгальтера }\end{array}$ \\
\hline & & 8 & $\begin{array}{l}\text { только незначительные ограничения; } \\
\text { способны выполнять действия при положении руки выше } \\
\text { уровня плеч }\end{array}$ \\
\hline & & 10 & нормальный уровень повседневной активности \\
\hline \multirow{6}{*}{3.} & \multirow{6}{*}{ Активное переднее сгибание } & 5 & 150 \\
\hline & & 4 & $120-150$ \\
\hline & & 3 & $90-120$ \\
\hline & & 2 & $45-90$ \\
\hline & & 1 & $30-45$ \\
\hline & & 0 & $<30$ \\
\hline \multirow{6}{*}{4.} & \multirow{6}{*}{ Сила переднего сгибания } & 5 & нормально \\
\hline & & 4 & хорошо \\
\hline & & 3 & удовлетворительно \\
\hline & & 2 & плохо \\
\hline & & 1 & мышечная концентрация \\
\hline & & 0 & ничего \\
\hline \multirow{2}{*}{5.} & \multirow{2}{*}{ Удовлетворенность пациента } & 5 & удовлетворен и лучше \\
\hline & & 0 & не удовлетворен и хуже \\
\hline \multicolumn{4}{|c|}{$\begin{array}{l}\text { Общий балл опросника: } \\
\text { Интерпретация: } \\
>27 \text { Хорошо/Отлично .................... < } 27 \text { удовлетворительно/плохо } \\
\text { Максимальное значение - } 35 \text { баллов. Отличные/хорошие отражают удовлетворительный результат, } \\
\text { где удовлетворительный/плохой - неудовлетворительный. }\end{array}$} \\
\hline
\end{tabular}

Шкала Константа (Constant Shoulder Score)

ФИО врача

ФИО пациента

Ответьте на все вопросы, выбирая только один ответ, если не указано иное

В течение предыдущих 4 недель

\begin{tabular}{|l|l|l|}
\hline \multirow{5}{*}{ Боль } & очень сильная & $\mathbf{0}$ \\
\cline { 2 - 3 } & сильная & $\mathbf{5}$ \\
\cline { 2 - 3 } & умеренная & $\mathbf{1 0}$ \\
\cline { 2 - 3 } Уровень активности (выберите подходящий ответ) & нет боли & $\mathbf{1 5}$ \\
\cline { 2 - 3 } & здоровый сон & да(2) нет (0) \\
\cline { 2 - 3 } & полноценный отдых/спорт & да (4) нет (0) \\
\hline \multirow{5}{*}{$\begin{array}{l}\text { Уровень, до которого вы можете поднять руку } \\
\text { на стороне пораженного сустава }\end{array}$} & до уровня поясницы выполнение обязанностей на работе & да) нет (0) \\
\cline { 2 - 3 } & до уровня мечевидного отростка & $\mathbf{2}$ \\
\cline { 2 - 3 } & до уровня шеи & $\mathbf{4}$ \\
\cline { 2 - 3 } & до уровня макушки & $\mathbf{6}$ \\
\cline { 2 - 3 } & выше уровня головы & $\mathbf{8}$ \\
\hline
\end{tabular}

52 Issues of Rehabilitation, Orthopaedics, Neurophysiology and Sport Promotion - IRONS 
RUSSIAN CULTURAL ADAPTATION OF MAIN SHOULDER ASSESSMENT SCORES: ASES, UCLA...

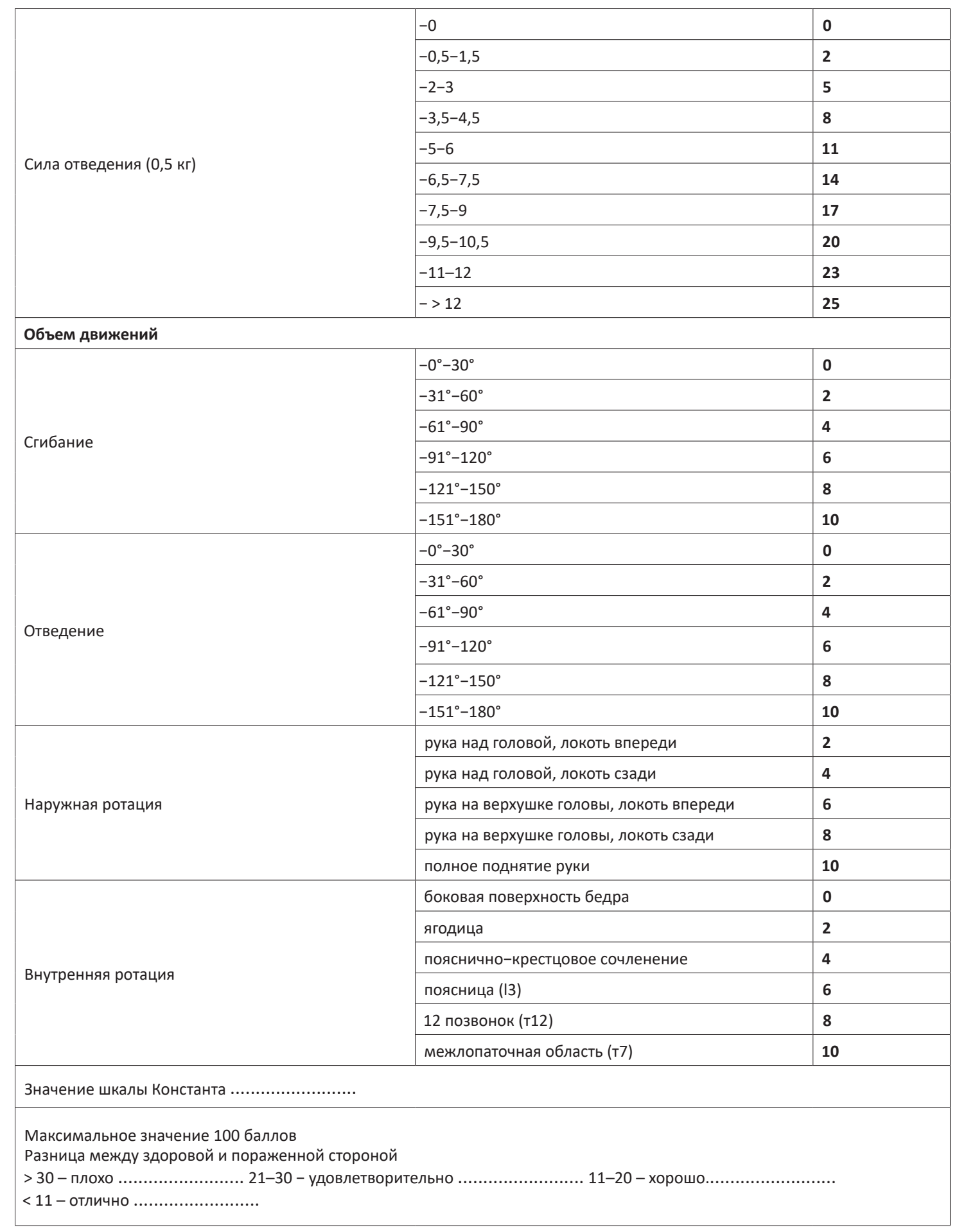

\section{Discussion}

The versions of the questionnaires that have been obtained as a result of the work done are ready for further use in various research papers and in regular practice. The adaptation algorithm used has already proven to be effective before in other countries. Not only were all questions translated, they were also thoroughly analyzed with regard to the country's specifics. It was established that translating medical terms accurately is especially important and challenging. Nevertheless, despite all the specifics identified and the adjustments that had to be made, none of the resulting questionnaires caused 
substantial misinterpretation. The next step was validation.

\section{Conclusion}

All the questionnaires translated and analyzed are widely used in many countries to assess the condition of the shoulder joint in patients with painful shoulder. Even so, given the specifics that every individual country possesses, each questionnaire should be adjusted in accordance with the specifics of the country where it is set to be used. What is most useful and efficient is multistage translation, where the resulting versions are analyzed, corrected and synthesized to obtain a version that is best adjusted to the local conditions and the specifics of the target language, as opposed to straightforward language-to-language translation. 


\section{REFERENCES}

Amstutz HC., Sew Hoy AL., Clarke IC. (1981)'UCLA anatomic total shoulder arthroplasty.' Clin. Orthop. Relat. Res., 155, pp. 7-20.

Beaton DE., Richards RR. (1996) 'Measuring function of the shoulder. A cross-sectional comparison of five questionnaires.' J. Bone Joint Surg. Am. 78(6), pp. 882-90.

Beaton D., Richards RR. (1998) 'Assessing the reliability and responsiveness of 5 shoulder questionnaires.' J. Shoulder Elbow Surg. 7(6), pp. 565-572.

Ebrahimzadeh MH., Birjandinejad A., Razi S., Mardani-Kivi M., Kachooei AR. (2015) 'Oxford Shoulder Score: A Cross-Cultural Adaptation and Validation Study of the Persian Version in Iran.' Iran J. Med. Sci., 40 (5), pp. 404-410.

Ellman H., Hanker G., Bayer M.(1986) 'Repair of the rotator cuff: end-result study of factors influencing reconstruction.' J. Bone Joint Surg., 68A, pp. 1136-1144.

Feleus A., Bierma-Zeinstra SM., Miedema HS., Bernsen RM., Verhaar JA., Koes B.W. (2008) Incidence of non-traumatic complaints of arm, neck and shoulder in general practice.' Man. Ther., 13, pp.426-33.

Gaudelli C., Balg F., Godbout V., Pelet S., Djahangiri A., Griffin S., Rouleau DM.

(2014) 'Validity, reliability and responsiveness of the French language translation of the Western Ontario Shoulder Instability In$\operatorname{dex}(W O S I)$.' Orthop Traumatol Surg Res., 100(1), pp. 99-103.

Godfrey J., Hamman R., Lowenstein S., Briggs K., Kocher M. (2007) 'Reliability, validity, and responsiveness of the simple shoulder test: psychometric properties by age and injury type.' J. Shoulder Elbow Surg. 16(3),pp. 260-7.

Greving K., Dorrestijn O., Winters JC., Groenhof F., van der Meer K., Stevens M. (2012) 'Incidence, prevalence, and consultation rates of shoulder complaints in general practice.' Scand. J. Rheumatol., 41, pp.150-5. Harvie P., Pollard TC., Chennagiri RJ. and Carr AJ. (2005) 'The use of outcome scores in surgery of the shoulder.' J. Bone Joint Surg. 87, pp. 151-154.

Lippitt ST., Harryman DT. II, Matsen FA. III (1992) 'A practical tool for evaluating function: the Simple Shoulder Test.' In: Matsen F.A. III, Fu F.H., Hawkins R.J., editors.'The Shoulder: A Balance of Mobility and Stability.' Rosemont (IL): American Academy of Orthopaedic Surgeons., pp.501-518.

Luime JJ., Koes BW., Hendriksen IJ., Burdorf A., Verhagen AP., Miedema HS. (2004) 'Prevalence and incidence of shoulder pain in the general population; a systematic review.' Scand. J. Rheumatol., 33, pp.73-81.

MacDermid JC., Drosdowech D., Faber K. (2006) 'Responsiveness of self-report scales in patients recovering from rotator cuff surgery. 'J Shoulder Elbow Surg. 15(4),pp. 407-14. Matsen FA. III, Ziegler DW., DeBartolo SE. (1995) 'Patient self-assessment of health status and function in glenohumeral degenerative joint disease.' J. Shoulder Elbow Surg. 4(5), pp. 345-51.

Michener LA., McClure PW., Sennett BJ. (2002) 'American Shoulder and Elbow Surgeons Standardized Shoulder Assessment Form, patient self-report section: reliability, validity, and responsiveness.' J Shoulder Elbow Surg. 11(6), pp. 587-594.

Neto JO., Gesser RL., Steglich V., Bonilauri Ferreira AP., Gandhi M., Vissoci JR., Pietrobon R.(2013) 'Validation of the Simple Shoulder Test in a Portuguese Brazilian Population. Is the Latent Variable Structure and Validation of the Simple Shoulder Test Stable across Cultures?' PLoS One, 8(5), e62890. Richards RR., An KN., Bigliani LU., Friedman RJ., Gartsman GM., Gristina AG., Iannotti JP., Mow VC., Sidles JA., Zuckerman JD. (1994) 'A standardized method for the assessment of shoulder function.' J. Shoulder Elbow Surg. 3(6),pp.347-52.

Rocourt MH, Radlinger L, Kalberer F, Sanavi S, Schmid NS, Leunig M, Hertel R. (2008) 'Evaluation of intratester and intertester reliability of the Constant-Murley shoulder assessment.' J Shoulder Elbow Surg.;17(2):364-9. 
Roddey TS., Olson SL., Cook KF., Gartsman GM., Hanten W. (2000) 'Comparison of the University of California-Los Angeles Shoulder Scale and the Simple Shoulder Test with the shoulder pain and disability index: single-administration reliability and validity.' Phys. Ther. 80(8), pp. 759-68.

Roe Y., Soberg HL., Bautz-Holter E., Ostensjo S. (2013) 'A systematic review of measures of shoulder pain and functioning using the International classification of functioning, disability and health (ICF).'BMC Musculoskelet. Disord. 28,pp. 73.

Romeo AA., Mazzocca A., Hang DW., Shott S., Bach BR. Jr. (2004) 'Shoulder scoring scales for the evaluation of rotator cuff repair.' Clin. Orthop. Relat. Res. 427, pp. 107-14. Ślęzak M., Lubiatowski P., Lubiatowski B., Łepski M., Imirowicz A., Romanowski L. (2016) 'Polish cultural adaptation of general shoulder assessment scores in use for painful shoulder: ASES, UCLA, Constant Score, SST (Part I). Preliminary study.' Issue Rehabil. Orthop. Neurophysiol. Sport Promot. 17, pp. 7-27.

Smith M. (2012) 'Upper Extremity-Specific Measures of Disability and Outcomes in Orthopaedic Surgery.' J. Bone Joint Surg. Am. 294, pp.277-85.

Tashjian RZ, Deloach J, Green A., Porucznik CA., Powell AP. (2010) 'Minimal clinically important differences in ASES and simple shoulder test scores after nonoperative treatment of rotator cuff disease. 'J. Bone Joint Surg. Am. 92(2), pp. 296-303.

Yaghjyan G., Abrahamyan D., Gevorgyan A. (2005). 'Cross-cultural adaptation of Armenian and Russian version of the Disabilities of the Arm, Shoulder and Hand (DASH) outcome measure.' Patient Reported Outcomes 34, pp. 7-8.

Wylie JD., Beckmann JT., Granger E., Tashjian RZ. (2014) 'Functional outcomes assessment in shoulder surgery'. World J. Orthop. 5, pp.623-633. 
Authors reported no source of funding. Authors declared no conflict of interest.

Author responsible for correspondence: Marina Lipina

Federal Science and Clinical Center of Federal Medical Biological Agency

115683

Russian Federation

Moscow

Orekhoviy b. 28

Trauma and Orthopedics Department-2 marina.lipina@icloud.com
Autorzy nie zgłosili źródła finansowania.

Autorzy nie deklarowali konfliktu interesów.

Autor odpowiedzialny za korespondencję:

Marina Lipina

Federal Science and Clinical Center of Federal Medical Biological Agency, Rosja

115683

Federacja Rosyjska

Moskwa

Orekhoviy b. 28

Oddział Urazowo-Ortopedyczny-2 marina.lipina@icloud.com 